\title{
FGFR1OP2/FGFR1 Fusion Gene
}

National Cancer Institute

\section{Source}

National Cancer Institute. FGFR1OP2/FGFR1 Fusion Gene. NCI Thesaurus. Code C99835.

A fusion gene that results from a chromosomal insertion ins(12;8)(p11;p11p22) that

fuses exon 4 of the FGFR1OP2 gene with exon 9 of the FGFR1 gene. This translocation is associated with 8p11 myeloproliferative disorder. 